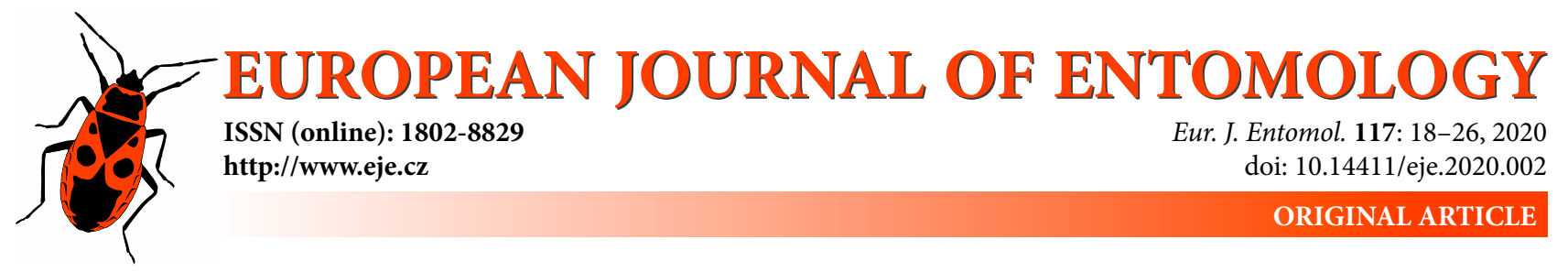

\title{
Taxonomic and functional differentiation of spiders in habitats in a traditional olive producing landscape in Italy
}

\author{
Malayka S. PICCHI ${ }^{1}$, Gionata BOCCI ${ }^{1}$, Ruggero PETACCHI ${ }^{1}$ and Martin H. ENTLING ${ }^{2}$ \\ ${ }^{1}$ Biolabs, Institute of Life Sciences, Scuola Superiore Sant'Anna, 56127, Pisa, Italy; e-mails: m.picchi@santannapisa.it, \\ boccigionata@gmail.com, r.petacchi@santannapisa.it \\ ${ }^{2}$ Institute for Environmental Sciences, Universität Koblenz - Landau, Fortstrasse 7, 76828, Landau, Germany; \\ e-mail: entling@uni-landau.de
}

Key words. Araneae, spider communities, perennial crop, semi-natural habitat, low-input management, beta diversity, edge

\begin{abstract}
Annual crops are generally assumed to host simplified arthropod communities that depend on immigration from the surrounding landscape. Perennial, low-input crops such as olive groves are likely to depend less on immigration from other habitats, however, studies on the landscape ecology of perennial crops are scarce. This paper studies the assemblages of arboreal spiders in three types of habitats adjoining olive groves: woods, garigue and other cultivated olive groves in a traditional olive producing landscape. Spiders were sampled during summer and the three types of habitats were compared in terms of species, families and functional groups in order to determine differences in diversity and the potential for spider spillover. As is often reported for annual crops, olive groves had a lower alpha and beta diversity than more natural habitats in terms of species, with a strong dominance of a single species, Frontinellina frutetorum (C.L. Koch, 1834). Differences in diversity between olive groves and natural habitats were not significant at family or functional group levels. With the possible exception of orb weavers, this study indicates that the spiders that were common in olive groves did not occur at higher densities in habitats that were more natural. This indicates there is limited spillover between perennial crops and other late-successional habitats. The enhancement of spiders in olive orchards for pest control may thus depend more on local management than on the presence of semi-natural habitats as a source of immigration.
\end{abstract}

\section{INTRODUCTION}

Agricultural landscapes are mosaics of different types of land use, with patches of heterogeneous semi-natural habitats (hereafter SNHs) interspersed among cultivated areas. How such a matrix of patches is arranged, which is often highly fragmented (Bennett \& Saunders, 2010), is known to strongly influence the composition of the hosted animal communities (Bennett et al., 2006), the biodiversity and provision of ecosystem services (Murcia, 1995). Habitat edges thus become important areas of immigration of animals from natural habitats into adjacent fields. Predators that spillover from natural habitats into crops are able to provide pest regulation services (Tscharntke et al., 2007). The behaviour of predators in both agricultural fields and surrounding habitats is therefore a major research field in the ecology of agricultural landscapes. (Chaplin-Kramer et al., 2011; Macfadyen \& Muller, 2013; Karp et al., 2018).

The spillover of natural enemies into agricultural fields depends on many variables (Hatley \& Macmahon, 1980; Murcia, 1995; Strayer et al., 2003; Rand et al., 2006; Ingrao et al., 2017). It can be limited by the lack of habitat suitability, by the difference in vegetation structure of habitats, by the specialisation of species and by the synchronization with resource availability (Samu et al., 1999; Tylianakis et al., 2004; Wamser et al., 2011; Inclán et al., 2016; Neuville et al., 2016). Thus, the highest exchange is expected between crops and natural habitats with similar habitat conditions. In addition, immigration tends to play a stronger role in annual compared to perennial crops because annual crops are inhabited by more mobile species than less disturbed habitats (Entling et al., 2011) and immigration may stabilize the guild structure of predators throughout the season (Leibold et al., 2004). As perennial crops provide food and shelter throughout the year (Costello \& Daane, 1999; Korenko \& Pekár, 2010), they are able to support more stable populations of natural enemies and depend less on immigration from adjacent non-crop vegetation.

Spiders are one of the most abundant groups of predators in olive groves (Morris et al., 1999; Cárdenas \& Barrientos, 2011) and contribute to pest control in agricultural fields (Hodge, 1999; Marc et al., 1999; Symondson et al., 2002; Michalko \& Pekár, 2015). Some case studies indicate they make a valuable contribution to limiting pest outbreaks despite their generalist foraging mode and occa- 
sional intraguild predation (Denno et al., 2004; Birkhofer et al., 2008; Michalko et al., 2019). Within olive groves, spiders may help suppress Bactrocera oleae, the olive fruit fly, which is a major pest (Picchi et al., 2016).

Another important issue regarding agroecosystems is their ability to support biodiversity, especially in the face of current insect declines (Paoletti et al., 1992; Paoletti, 1995). In fact, traditional olive groves, with a prevalence of ancient olive trees in a complex habitat structure in combination with the Mediterranean climate and low-input management, are considered to be high nature value farmland (Tartaglini \& Calabrese, 2012). Thus, olive groves are likely to support ecosystem services (soil and water quality, carbon sequestration) and have a high biodiversity, which could foster diverse spider communities all year round. For example, spiders overwinter in high abundance in other perennial crops such as vineyards (Costello \& Daane, 1999), whereas spider overwintering in temperate annual crops is limited (Pfiffner \& Luka, 2000; Mestre et al., 2018). Thus, olive groves have the potential to host diverse spider assemblages, as is known for vineyards (Košulič et al., 2014).

Pest suppression by spiders is affected by several factors, such as life history traits and intraguild interactions (Takada et al., 2013). A functional approach should thus be adopted when studying their effectiveness for pest control (Cardoso et al., 2011).

The functional classification of spiders is based on different parameters: in the present study we grouped individuals into guilds according to their foraging strategy, since this may reflect resource use within a particular habitat (Uetz et al., 1999).

In a typical Mediterranean olive-grove landscape, we tested the following hypotheses:

(i) there is a lower alpha and beta diversity of spiders in olive groves than in adjacent semi-natural habitats;

(ii) spider communities in different habitats differ and are affected by the characteristics of the upper layers of vegetation (shrubs and trees);

(iii) the abundance of the most numerous spider families and species depends on the type of habitat and structure of the upper layers of vegetation (shrubs and trees).

Hypotheses (i) and (ii) were tested for spider species, spider families and spider functional groups.

\section{MATERIALS AND METHODS}

\section{Study area}

The area studied is a hilly region of approximately $160 \mathrm{~km}^{2}$

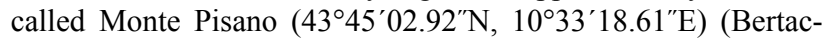
chi et al., 2004). It is located in central northern Tuscany and is mostly a traditional olive oil producing area. Olive groves are characterized by the presence of the historical terraced system for water drainage (Rizzo et al., 2007) and are managed as low input systems, with old trees growing at a low density (circa 100 trees/ ha) (Duarte et al., 2008). The areas of garigue, woods and other olive groves studied included the three types of edges that most commonly border olive groves in the area studied. We selected six olive groves ("OL") next to other olive groves, six woods that bordered olive groves ("WA") and six areas of shrub land that bordered olive groves ("GA": Mediterranean garigue). Within these 18 habitats, both the spiders and vegetation were sampled (for a map, see Fig. S1 in Supplementary Material).

\section{Spider sampling}

In each habitat two sampling points, $10 \mathrm{~m}$ apart, were established and at each point, the spiders in the canopies of trees and shrubs were sampled. All the sampling points were located at the edge bordering on adjacent olive groves. Spiders were sampled both by hand collecting and with a beating tray, four times from June to October 2014.

Hand collecting consisted in actively searching for spiders in the canopy for eight minutes at each sampling point, whereas beating entailed collecting spiders that dropped from branches of trees or shrubs at each sampling point. Four branches, one in each cardinal direction, were beaten 10 times and the arthropods that fell on to the $35 \mathrm{~cm}$ diameter beating tray were collected. Spiders were preserved in $70 \%$ ethanol, counted and identified to species level (Roberts, 1987; Trotta, 2004; Nentwig et al., 2019; Oger, 2019), using current nomenclature (World Spider Catalog, 2019).

Juveniles were assigned to a species only when they had clear characteristics (Larrivée \& Buddle, 2009). Spiders were also divided into functional groups, following Uetz's classification (Uetz et al., 1999), based on different spider hunting strategies (ambushers, foliage runners, ground runners, orb weavers, sheet web builders, space web builders, stalkers, wandering sheet/tangle weavers). Cumulative counts of spiders collected, using both sampling methods and on all the dates sampled, were used as measures of abundance and species richness.

\section{Vegetation sampling}

Within each habitat, the most abundant shrubs and trees were identified to species level and the mean percentage ground cover of the tree (height $>4 \mathrm{~m}$ ) and shrub (1-4 m height) layer was estimated visually. The surveys took place only once at the beginning of the sampling season since these variables do not usually change throughout the sampling period given that such habitats are either not managed (e.g. garigue) or, when managed, operations were carried out later in the season (e.g. pruning in olive groves).

\section{Statistical analysis}

All analyses were carried out using R ( R Development Core Team, 2016). To test for differences in beta diversity between habitats, we assessed the homogeneity in the dispersion of spider groups across different types of field-margins using the "betadisper" function in the "vegan" package (Oksanen et al., 2015). Bray-Curtis distances were calculated as the inputs for the analysis of beta diversity. Differences among groups were assessed via Anova and then a post-hoc Tukey "Honest Significant Difference" was run to highlight differences in beta diversity among habitats ("stats" package).

Differences in the community composition in the different habitats were assessed using redundancy analysis $(r d a)$ in which the constraining (environmental) variables were type of habitat ("WA", "GA", "OL") and the mean percentage ground cover of the shrub and tree layers at each sampling points. The raw spider community data were standardized using Hellinger distance prior to the $r d a$, as suggested by Legendre \& Gallagher (2001).

Model testing of hypotheses (i) and (ii) was done for three levels of spider communities: first the number of individuals per species, second the number of individuals per family and third for the number of individuals per hunting guild (hypothesis iii).

Differences between habitats for the most abundant families (Araneidae, Linyphiidae, Theridiidae) and the single most abundant species (Frontinellina frutetorum) were tested using gener- 
alized linear models (GLM) with numbers of individuals as the dependent variable, while the predictors were habitat and percentage of ground covered by the shrub and tree layers. GLM models were run using a Poisson distribution. In cases where the models were over dispersed [tested using the "dispersiontest" function in the AER package (Kleiber \& Zeileis, 2008)] a negative binomial GLM was fitted using the "glm.nb" function in the MASS package (Venables \& Ripley, 2002). A model selection procedure was then applied adopting a likelihood ratio test as suggested by Lewis et al. (2011).

\section{RESULTS}

\section{Vegetation}

Among the woods sampled, there were two pure pine stands (Pinus pinaster Aiton), four evergreen Mediterranean forests dominated by Quercus ilex L. and containing other tree species such as Fraxinus ornus L., Arbutus unedo L., chestnut (Castanea sativa L.), Ulmus minor Mill., Cupressus sempervirens L., Juglans regia L. and two invasive species, Robinia pseudacacia L. and Ailanthus altissima (Mill.) Swingle.

The garigue stands studied were characterized by dry rocky soils that host shrub land dominated by Erica sp. (Polunin \& Walters, 1985). Mean ground cover of the tree layer was generally low in the garigue $(0.17 \pm 0.1, \mathrm{n}=6)$, compared to woods $(0.87 \pm 0.1)$ and groves $(0.82 \pm 0.03)$. The highest ground cover of shrubs was recorded in woods $(0.58 \pm 0.16)$, intermediate values in garigue areas $(0.30$ \pm 0.08 ) and was practically nil in olive groves (only one plot contained shrubs). This is because the grass is usually mown at least once a year to facilitate olive fruit collection and the ground is thus covered with species of herbaceous annuals.

\section{Spiders}

We collected 957 specimens belonging to 38 species: 291 individuals of 12 species in the olive, 303 individuals from 14 species of Mediterranean garigue, and 363 of 31 species in the woods (see Table S1 in Supplementary Material for a complete species list). The dominant families were Linyphiidae (31.5\% of individuals), Araneidae (18.2\%) and Theridiidae (9.5\%). The dominant species was the linyphiid Frontinellina frutetorum (C.L. Koch, 1834), which in the olive groves made up to $61.8 \%$ of all the spiders collected. The abundances of all the three dominant families and that of $F$. frutetorum, were influenced by the type of semi-natural habitat (see Table 1), while other vegetation parameters (ground cover of shrubs and trees) had no effect on spider abundance.

Among identified species, the dominant functional group was web builders $(80.9 \%)$. Among active hunters, stalkers were the most abundant (13.3\% of the overall community). Web builders were the most abundant group in all three habitats, though with a varying distribution of the different guilds. In the olive groves, tangle spiders were the most abundant group (80.8\%). In the garigue and margins of woods, orb weavers were dominant $(43.2 \%$ and $44 \%$, respectively) and cursorial species were present at lower percentages. The garigue hosted a higher number of stalkers $(24.2 \%)$, while a higher abundance of ambushers was recorded at the margins of woods $(22.5 \%)$.

The beta diversity was lower between olive groves than in the garigue or woodlands, but the difference was significant only at the species level $\left(\mathrm{P}<0.001, \mathrm{~F}_{2,15}=16.20\right.$, top plots in Fig. 1). When the analysis was performed either at the family level $\left(\mathrm{P}=0.24, \mathrm{~F}_{2,15}=1,58\right.$, middle plots in Fig. $1)$ or using a functional group classification $\left(\mathrm{P}=0.53, \mathrm{~F}_{2,15}\right.$ $=0.67$ bottom plots in Fig. 1), differences in beta diversity between habitats were non-significant.

The compositions of the spider communities differed significantly between habitats at all levels (species, families, and functional groups); with no significant effect of vegetation structure (Table 2, Fig. 1).

Of the spider families, Linyphiidae were most abundant in olive groves and least abundant in garigue (Fig. 2a, $\left.\chi_{2,18}^{2}=56.62, \mathrm{P}<0.001\right)$. Theridiidae were more abundant in garigue than in the two other habitats (Fig. $2 b, \chi_{2,18}^{2}$ $=13.38, \mathrm{P}=0.001)$ and Araneidae were less abundant in olive groves than in the other two habitats (Fig. $2 \mathrm{c}, \chi_{2,18}^{2}=$ $11.28, \mathrm{P}=0.003$ ). The strongly dominant species, $F$. frutetorum was more abundant in olive groves than in the other habitats (Fig. $2 \mathrm{~d} \chi_{2,18}^{2}=42.85, \mathrm{P}<0.001$ ).

\section{DISCUSSION}

Our results highlight that woods are the habitat with the highest spider species richness at the canopy level, whereas olive groves, even when managed as a traditional low-intensive system, host a smaller number of species of spiders with a high compositional similarity across sites. The low diversity of spiders in olive groves is surprising since it is considered as an agroecosystem capable of supporting a high level of biodiversity, i.e. a "High Nature Value Farmland" (Tartaglini \& Calabrese, 2012). Thus, the homogenization effect would be expected to be less strong

Table 1. Results of the negative binomial GLM model of the abundances of spider families and the dominant species, Frontinellina frutetorum, in olive groves. The first column is the dependent variable, the second, third and fourth columns the results of the likelihood-ratio test values $\left(\mathrm{X}^{2}\right)$ for the predictors (namely, habitat in the field margin, the percentage ground cover of shrubs and of trees) and in parenthesis the corresponding degrees of freedom; the last column indicates the number of observations. "n.s." indicates that the predictor was dropped from the minimum adequate model. Model selection was based on Bayes. ${ }^{* * *} p<0.001 ;{ }^{* *} p<0.01$.

\begin{tabular}{lccc}
\hline Outcome variable & Habitat & Shrub cover & Tree cover \\
\hline Linyphiidae & $56.62^{* *}(2)$ & n.s. & Observations \\
Theridiidae & $13.38^{* *}(2)$ & n.s. & n.s. \\
Araneidae & $11.28^{* *}(2)$ & n.s. & n.s. \\
Frontinellina frutetorum & $42.85^{\star * *}(2)$ & n.s. & n.s. \\
\hline
\end{tabular}




\section{Spider species}

a)

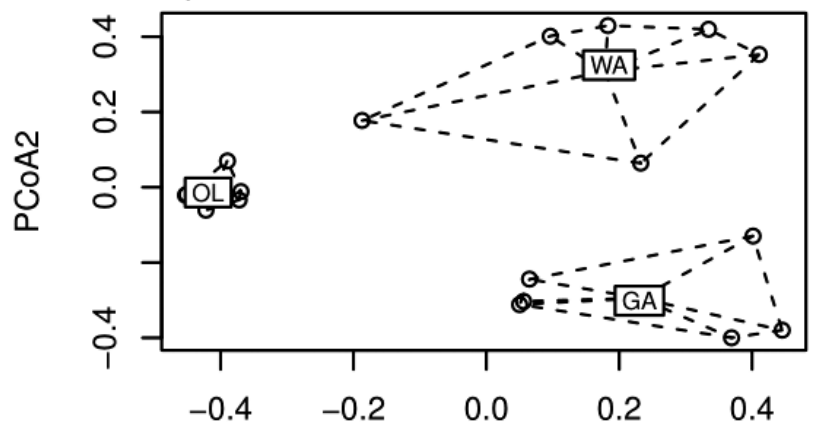

b)

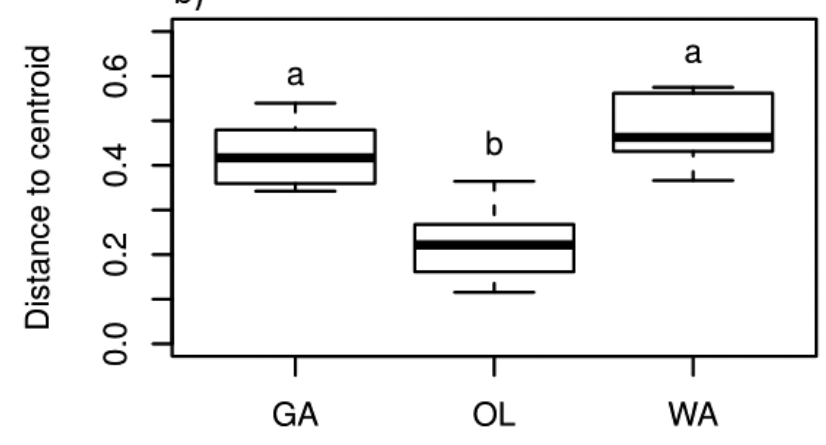

PCoA1

\section{Spider families}
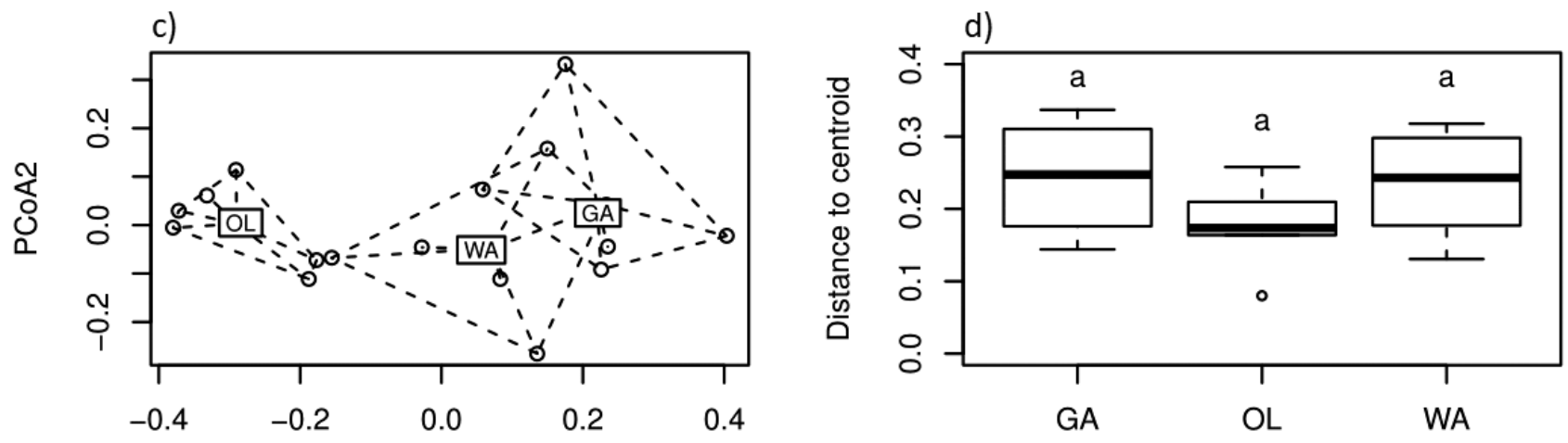

PCoA1

\section{Spider functional groups}

e)

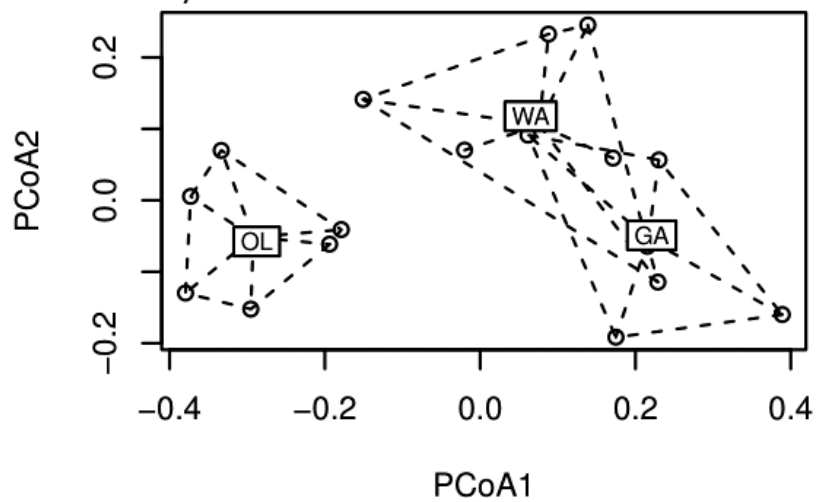

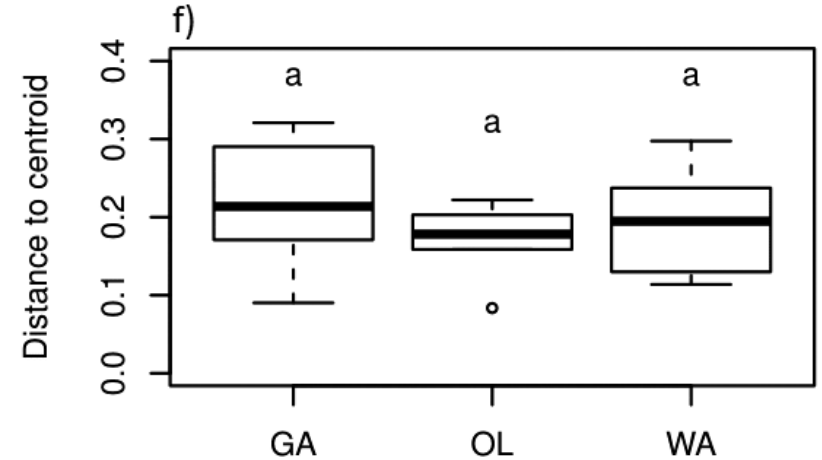

Fig. 1. Difference in species composition of the spider communities $(a, c, e)$ and beta diversity $(b, d, f)$ of spiders in the different habitats. Communities are structured at the level of species (a, b), family (c, d) and functional group (e, f). WA - woods, GA - garigue, OL - olive grove. Letters represent significant differences $(p<0.05)$ based on Tukey Honest Significant Differences.

or absent (Newbold et al., 2015). However, our analysis shows that biodiversity is lower than that recorded in more near-natural vegetation, at least for arboreal spiders.

The homogenization effect indicates that environmental filtering in olive groves strongly constrains the range of species that are able to exist in such communities (Leibold et al., 2004). The dominance of a single tree species, absence of a shrub layer and pesticides may all contribute to the low diversity of spiders in olive groves (Dormann et al., 2007). For example, conventionally managed olive groves receive up to three pesticide treatments against the olive fruit fly per year, whereas in organic groves sub- 


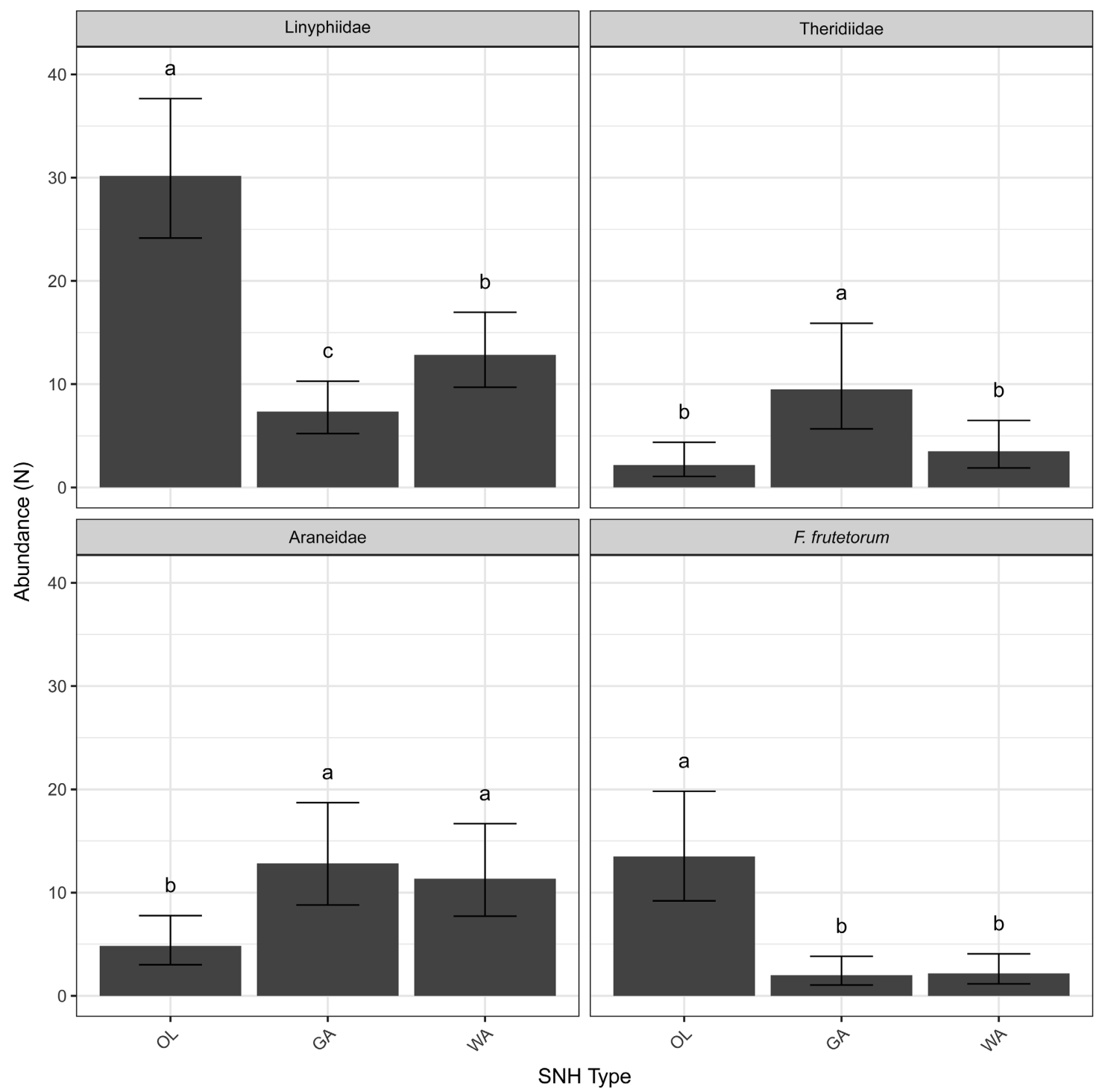

Fig. 2. Individuals per orchard of the dominant spider families and species in the three habitats. Bars represent the $95 \%$ confidence intervals; letters represent significant differences $(p<0.05)$ based on Tukey Honest Significant Differences.

stances certified for organic farming are used (regulated by CE 834/2007 and subsequent updates). The biotic homogenization effect in olive groves is particularly clear at the species level: the linyphiid species $F$. frutetorum was dominant in all olive groves (Picchi et al., 2016).

As the spider communities in olive groves were very distinct from those in natural habitats and largely composed of a species that was less abundant in more natural habitats, it seems that olive groves are an agroecosystem with little potential for spider species spillover from nearby richer habitats. This is similar to annual crops in arid regions, in which the arthropod communities are often dominated by a single or a few species (Prieto-Benítez \& Méndez, 2011; Opatovsky \& Lubin, 2012; Opatovsky et al., 2017) and, among spiders, linyphiids tend to dominate such communities due to their good dispersal ability.

Table 2. Significance of the marginal effects of the rda models used to assess the influence of environmental variables on species composition of spider communities: rows are the predictors (habitat adjacent to olive groves: WA - woods, GA - Mediterranean garigue, OL - olive grove); tree and shrub cover: ground cover of the tree/shrub layer; three models were run, which analysed spiders at the species level (main column 1), family level (main column 2) and functional group (sensu Uetz) level (main column 3 ). Rda models were run on the Hellinger transformed dataset using 999 permutations. ${ }^{* * *} p<0.001,{ }^{* *} p<0.01,{ }^{*} p<0.05$.

\begin{tabular}{|c|c|c|c|c|c|c|c|}
\hline & \multirow{2}{*}{ df } & \multicolumn{2}{|c|}{ Species } & \multicolumn{2}{|c|}{ Family } & \multicolumn{2}{|c|}{ Functional group } \\
\hline & & $F$ & $P$ & $F$ & $P$ & $F$ & $P$ \\
\hline Shrub cover (\%) & 1 & 1.32 & 0.22 & 1.18 & 0.33 & 1.57 & 0.19 \\
\hline Tree cover (\%) & 1 & 1.14 & 0.32 & 0.53 & 0.79 & 0.53 & 0.73 \\
\hline Habitat type & 2 & 3.25 & $<0.01^{* * *}$ & 2.16 & $0.02^{*}$ & 2.87 & $0.01^{*}$ \\
\hline Residual & 13 & n.s. & n.s. & n.s. & n.s. & n.s. & n.s. \\
\hline
\end{tabular}


In our study, the linyphiid $F$. frutetorum dominated in canopies of olive trees and its abundance was lower but still significant in other SNH edges. The potential role of this spider in providing pest control services against the olive fruit fly merits further investigation. In spite of the uniform dominance of $F$. frutetorum, other studies on the species composition of spiders in other olive groves in the area studied report some Apennine or Tyrrhenian endemic and uncommon species such as Cybaeodes marinae Di Franco, 1989 and Ozyptila salustri Wunderlich, 2011 (M.S. Picchi, unpubl. data).

The abundance and species richness of spiders were higher in woods than in the other habitats. The three dimensional structures of the edges of perennial woods probably provide a greater availability of alternative food supplies and shelter and suitable microclimate conditions (Herrmann et al., 2010; Pfister et al., 2015). These conditions enhance the survival and reproductive rates of spiders (Landis et al., 2000) and thus the possibility of them hosting a high diversity of species. The higher density of araneids in adjoining woods and garigue compared to olive groves corresponds well with the increase in araneids within olive groves towards the edges of this habitat (Picchi et al., 2016).

An additional environmental parameter that could have a positive influence on the species composition of spider communities is the type and complexity of the litter, which is unmanaged within woody areas (Uetz, 1979). The lower species richness found in Mediterranean garigue may be due to the low levels of humidity (Nentwig, 1987) found in such habitats, a factor which is known to affect groups such as linyphiids that are typically associated with humid environments (Kumschick et al., 2009).

Although the differences in community composition in different types of habitats were significant at all the levels studied, the lower beta diversity recorded in olive groves compared to more natural habitats was significant only at the species level. This indicates that using land for agriculture results in a decrease in biodiversity at the species level more than at the family or functional group level, even in complex perennial agroecosystems such as olive groves, which are generally considered as being part of a lowimpact agriculture. Consequently, enhancing spiders in olive orchards for pest control may depend more on local management than on the provision of SNHs as sources of immigration. Possible management strategies in favour of spiders are organic farming (Picchi et al., 2016) and a reduced pesticide input along with an appropriate selection and timing of the application of chemicals (Dix et al., 1995) if we are to preserve the abundance of these natural enemies.

ACKNOWLEDGEMENTS. This work is a part of QuESSA project and has received funding from the European Union's Seventh Framework Program for research, technological development and demonstration under grant agreement No. 311879. We greatly appreciate the cooperation of the farmers of whose fields were included in this study and thank all colleagues involved and C.
Moonen as supervisor of the project. We gratefully acknowledge all the reviewers for their improvements.

\section{REFERENCES}

BenNetT A.F. \& SAunders D.A. 2010: Habitat fragmentation and landscape change. In Sodhi N.S. \& Ehrlich P.R. (eds): Conservation Biology for All. Oxford University Press, Oxford, pp. 88-104.

Bennett A.F., Radford J.Q. \& Haslem A. 2006: Properties of land mosaics: Implications for nature conservation in agricultural environments. - Biol. Conserv. 133: 250-264.

Bertacchi A., SAni A. \& Tomei P.E. 2004: La Vegetazione del Monte Pisano. Felici, Pisa, 36 pp.

Birkhofer K., Gavish-Regev E., Endlweber K., Lubin Y.D., von Berg K., Wise D.H. \& Scheu S. 2008: Cursorial spiders retard initial aphid population growth at low densities in winter wheat. - Bull. Entomol. Res. 98: 249-255.

CÁrdenas M. \& Barrientos J. 2011: Arañas del olivar andaluz (Arachnida; Araneae). Aspectos faunísticos. — Zool. Baetica 99-136.

Cardoso P., Pekár S., Jocqué R. \& Coddington J.A. 2011: Global patterns of guild composition and functional diversity of spiders. - PLOS ONE 6(6): e21710, 10 pp.

Chaplin-Kramer R., O’Rourke M.E., Blitzer E.J. \& Kremen C. 2011: A meta-analysis of crop pest and natural enemy response to landscape complexity. - Ecol. Lett. 14: 922-932.

Costello M. \& DaAne K.M. 1999: Abundance of spiders and insect predators on grapes in central California. - J. Arachnol. 27: 531-538.

Denno R.F., Mitter M.S., Langellotto G.A., Gratton C. \& FINKE D.L. 2004: Interactions between a hunting spider and a web-builder: Consequences of intraguild predation and cannibalism for prey suppression. - Ecol. Entomol. 29: 566-577.

Dix M.E., Johnson R.J., Harrell M.O., Case R.M., Wright R.J., Hodges L., Brandle J.R., Schoeneberger M.M., Sunderman N.J., Fitzmaurice R.L., Young L.J. \& Hubbard K.G. 1995: Influences of trees on abundance of natural enemies of insect pests: a review. - Agroforestry 29: 303-311.

Dormann C.F., Schweiger O., Augenstein I., Bailey D., Billeter R., De Blust G., Defilippi R., Frenzel M., Hendrickx F., HerZOG F. ET AL. 2007: Effects of landscape structure and land-use intensity on similarity of plant and animal communities. Glob. Ecol. Biogeogr. 16: 774-787.

Duarte F., Jones N. \& Fleskens L. 2008: Traditional olive orchards on sloping land: sustainability or abandonment? $-J$. Environ. Manag. 89: 86-98.

ENTLING M.H., STÄMPFLI K. \& OVASKAINEN O. 2011: Increased propensity for aerial dispersal in disturbed habitats due to intraspecific variation and species turnover. - Oikos 120: 1099-1109.

Hatley C.L. \& Macmahon J.A. 1980: Spider community organization: Seasonal variation and the role of vegetation architecture. - Environ. Entomol. 9: 632-639.

Herrmann J.D., Bailey D., Hofer G., Herzog F. \& SchmidtENTLING M.H. 2010: Spiders associated with the meadow and tree canopies of orchards respond differently to habitat fragmentation. - Landsc. Ecol. 25: 1375-1384.

Hodge M.A. 1999: The implications of intraguild predation for the role of spiders in biological control. - J. Arachnol. 27: 351-362.

Inclán D.J., Dainese M., Cerretti P., Paniccia D. \& Marini L. 2016: Spillover of tachinids and hoverflies from different field margins. - Basic Appl. Ecol. 17: 33-42.

Ingrao A.J., Schmidt J., Jubenville J., Grode A., Komondy L., VanderZee D. \& Szendrei Z. 2017: Biocontrol on the edge: 
Field margin habitats in asparagus fields influence natural enemy-pest interactions. - Agric. Ecosyst. Environ. 243: 47-54.

Karp D.S., Chaplin-Kramer R., Meehan T.D., Martin E.A., DeClerck F., Grab H., Gratton C., Hunt L., Larsen A.E., Martínez-Salinas A. ET AL. 2018: Crop pests and predators exhibit inconsistent responses to surrounding landscape composition. - Proc. Natl. Acad. Sci. 115: E7863-E7870.

Kleiber C. \& ZeILeIs A. 2008: Applied Econometrics with $R$. Springer, New York, 222 pp.

Korenko S. \& PeKÁr S. 2010: Is there intraguild predation between winter-active spiders (Araneae) on apple tree bark? Biol. Contr. 54: 206-212.

Košulič O., Michalko R. \& Hula V. 2014: Recent artificial vineyard terraces as a refuge for rare and endangered spiders in a modern agricultural landscape. - Ecol. Engin. 68: 133-142.

Kumschick S., Schmidt-Entling M.H., Bacher S., Hickler T., ENTLING W. \& Nentwig W. 2009: Water limitation prevails over energy in European diversity gradients of sheetweb spiders (Araneae: Linyphiidae). - Basic Appl. Ecol. 10: 754-762.

Landis D.A., Wratten S.D. \& GuRR G.M. 2000: Habitat management to conserve natural enemies of arthropod pests. - Annu. Rev. Entomol. 45: 175-201.

LARRIVÉE M. \& BuddLE C.M. 2009: Diversity of canopy and understorey spiders in north-temperate hardwood forests. Agric. For. Entomol. 11: 225-237.

Legendre P. \& Gallagher E.D. 2001: Ecologically meaningful transformations for ordination of species data. - Oecologia 129: $271-280$.

Leibold M.A., Holyoak M., Mouquet N., Amarasekare P., Chase J.M., Hoopes M.F., Holt R.D., Shurin J.B., Law R., Tilman D., Loreau M. \& Gonzalez A. 2004: The metacommunity concept: A framework for multi-scale community ecology. Ecol. Lett. 7: 601-613.

Lewis F., Butler A. \& Gilbert L. 2011: A unified approach to model selection using the likelihood ratio test. - Methods Ecol. Evol. 2: 155-162.

Macfadyen S. \& Muller W. 2013: Edges in agricultural landscapes: Species interactions and movement of natural enemies. - PLoS ONE 8(3): e59659, 8 pp.

Marc P., CANARd A. \& Ysnel F. 1999: Spiders (Araneae) useful for pest limitation and bioindication. - Agric. Ecosyst. Environ. 74: 229-273.

Mestre L., Schirmel J., Hetz J., Kolb S., Pfister S.C., Amato M., Sutter L., Jeanneret P., Albrecht M. \& Entling M.H. 2018: Both woody and herbaceous semi-natural habitats are essential for spider overwintering in European farmland. - Agric. Ecosyst. Environ. 267: 141-146.

Michalko R. \& PeKÁr S. 2015: Niche partitioning and niche filtering jointly mediate the coexistence of three closely related spider species (Araneae, Philodromidae). - Ecol. Entomol. 40: 22-33.

Michalko R., Pekár S., Dul'A M. \& Entling M.H. 2019: Global patterns in the biocontrol efficacy of spiders: A meta-analysis. - Glob. Ecol. Biogeogr. 18: 1366-1378.

Morris T.I., Campos M., Kidd N.A.C., Jervis M.A. \& Symondson W.O.C. 1999: Dynamics of the predatory arthropod community in Spanish olive grove. - Agric. For. Entomol. 1: 219-228.

MurCIA C. 1995: Edge effects in fragmented forests: implications for conservation. - Trends Ecol. Evol. 10: 58-62.

Nentwig W. 1987: Ecophysiology of Spiders. Springer, Berlin, Heidelberg, New York, 448 pp.

Nentwig W., Blick T., Gloor D. \& Hänggi A.C.K. 2019: Spiders of Europe. URL: https://araneae.unibe.ch/ (last accessed $27 \mathrm{Jul}$. 19).
Neuville S., Le Ralec A., Outreman Y. \& Jaloux B. 2016: The delay in arrival of the parasitoid Diaeretiella rapae influences the efficiency of cabbage aphid biological control. - BioControl 61: 115-126.

Newbold T., Hudson L.N., Hill S.L.L., Contu S., Lysenko I., Senior R.A., Börger L., Bennett D.J., Choimes A., Collen B., ET AL. 2015: Global effects of land use on local terrestrial biodiversity. - Nature 520: 45-50.

Oger P. 2019: Les Araignées de Belgique et de France. URL: https://arachno.piwigo.com/ (last accessed 9 Aug. 18).

Oksanen A.J., Blanchet F.G., Kindt R., Minchin P.R., Hara R.B.O., Simpson G.L., Soly P., Stevens M.H.H. \& Wagner H. 2015: Vegan: Community Ecology Package. Version 2.3-2.

Opatovsky I. \& Lubin Y. 2012: Coping with abrupt decline in habitat quality: Effects of harvest on spider abundance and movement. - Acta Oecol. 41: 14-19.

Opatovsky I., Weintraub P.G., Musli I. \& Lubin Y. 2017: Use of alternative habitats by spiders in a desert agroecosystem. $-J$. Arachnol. 45: 129-138.

Paoletti M.G. 1995: Biodiversity, traditional landscapes and agroecosystem management. - Landsc. Urban Plan. 31: $117-128$.

Paoletti M.G., Pimentel D., Stinner B.R. \& Stinner D. 1992: Agroecosystem biodiversity: matching production and conservation biology. - Agric. Ecosyst. Environ. 40: 3-23.

PFIFFNER L. \& LUKA H. 2000: Overwintering of arthropods in soils of arable fields and adjacent semi-natural habitats. - Agric. Ecosyst. Environ. 78: 215-222.

Pfister S.C., Schafer R.B., Schirmel J. \& Entling M.H. 2015: Effects of hedgerows and riparian margins on aerial web-building spiders in cereal fields. - J. Arachnol. 43: 400-405.

Picchi M.S., Bocci G., Petacchi R. \& Entling M.H. 2016: Effects of local and landscape factors on spiders and olive fruit flies. Agric. Ecosyst. Environ. 222: 138-147.

Polunin O. \& Walters M. 1985: A Guide to the Vegetation of Britain and Europe. Oxford University Press, Oxford, New York, $238 \mathrm{pp}$.

Prieto-Benítez S. \& Méndez M. 2011: Effects of land management on the abundance and richness of spiders (Araneae): A meta-analysis. - Biol. Conserv. 144: 683-691.

R Development Core Team R. 2016: R: A Language and Environment for Statistical Computing. R Foundation for Statistical Computing, URL: https://doi.org/10.1007/978-3-540-74686-7.

Rand T.A., Tylianakis J.M. \& TscharntKe T. 2006: Spillover edge effects: The dispersal of agriculturally subsidized insect natural enemies into adjacent natural habitats. - Ecol. Lett. 9: 603-614.

Rizzo D., Galli M., Sabbatini T. \& Bonari E. 2007: The geoagronomic approach to the rural landscapes management: a methodological path to characterize contemporary challenges. In: 25 Years of Landscape Ecology: Scientific Principles in Practice. Proceedings of the 7th IALE World Congress. Vol. 2. Wageningen, pp. 805-806.

RoBERTS M.J. 1987: The Spiders of Great Britain and Ireland. Harley Books, Colchester, 204 pp.

Samu F., Sunderland K.D. \& Szinetár C. 1999: Scale-dependent dispersal and distribution patterns of spiders in agricultural systems: A review. - J. Arachnol. 27: 325-332.

Strayer D.L., Power M.E., Fagan W.F., Pickett S.T.A. \& BelNAP J. 2003: A classification of ecological boundaries. - Bioscience 53: 723-729.

Symondson W.O.C., Sunderland K.D. \& Greenstone M.H. 2002: Can generalist predators be effective biocontrol agents? - Plant Sci. 47: 561-594. 
Takada M.B., Kabayashi T., Yoshioka A., Takagi S. \& WashiTANI I. 2013: Facilitation of ground-dwelling spider predation on mirid bugs by horizontal webs built by Tetragnatha spiders in organic paddy fields. - J. Arachnol. 41: 31-35.

TARTAGLINI N. \& CALABRESE G.J. 2012: Ancient olive orchards as high nature value farmland: a shared vision at Euro-Mediterranean level. In La Posta A. \& Lacirignola C. \& Mimiola G. (eds): A Multi-Scale and Multi-Level Approach for Conservation of Ancient Olive Orchards in the Euro-Mediterran Region. CIHEAM - Mediterranean Agronomic Institute of Bari, Valenzano, pp. 27-42.

Trotтa A. 2004: Introduzione ai ragni italiani. - Mem. Soc. Entomol. Ital. 83: 3-178.

Tscharntke T., Bommarco R., Clough Y., Crist T.O., Kleijn D., Rand T.A., Tylianakis J.M., Nouhuys S. Van \& Vidal S. 2007: Conservation biological control and enemy diversity on a landscape scale. - Biol. Contr. 43: 294-309.

TYLianakis J.M., Didham R.K. \& Wratten S.D. 2004: Improved fitness of aphid parasitoids receiving resource subsidies. Ecology 85: 658-666.

Uetz G.W. 1979: The influence of variation in litter habitats on spider communities. - Oecologia 40: 29-42.

Uetz G.W., Halaj J. \& Cady A.-B. 1999: Guild structure of spiders in major crops. - J. Arachnol. 27: 270-280.

Venables W.N. \& Ripley B.D. 2002: Modern Applied Statistics with $S$. Springer, New York, 504 pp.

Wamser S., Dauber J., Birkhofer K. \& Wolters V. 2011: Delayed colonisation of arable fields by spring breeding ground beetles (Coleoptera: Carabidae) in landscapes with a high availability of hibernation sites. - Agric. Ecosyst. Environ. 144: $235-240$.

World Spider Catalog 2019: World Spider Catalog. Version 20.5. URL: https://doi.org/10.24436/2.

Received July 22, 2019; revised and accepted December 9, 2019 Published online January 22, 2020

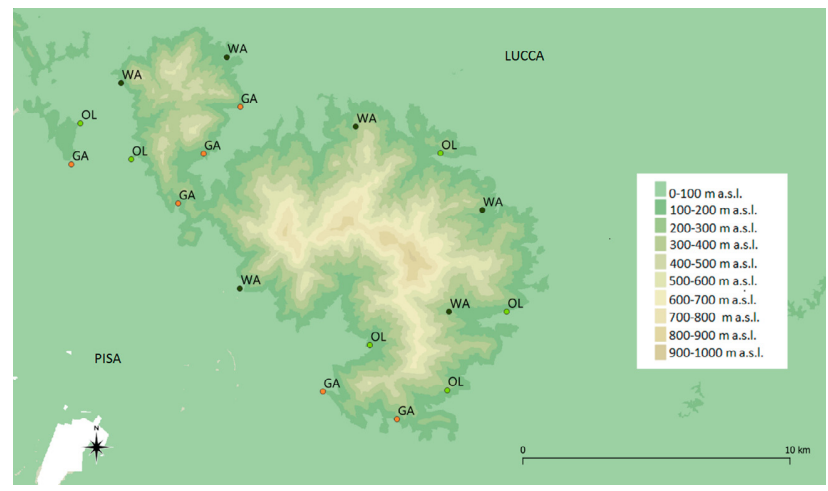

Fig. S1. Location of the 18 experimental olive groves in the Monte Pisano area (between the province of Pisa and Lucca). The legend indicates the altitude. Sites were differentiated by the type of Adjacent SNH (GA - Mediterranean garigue; WA - wood; OL - olive grove).
Table S1. List of species of spiders captured at the borders of olive groves in the Monte Pisano area adjacent to Olive groves, Garigue and Woodland.

\begin{tabular}{|c|c|c|c|c|c|}
\hline \multirow{2}{*}{$\begin{array}{l}\text { Functional group } \\
\text { (Uetz et al., 1999) }\end{array}$} & \multirow{3}{*}{ Family } & \multirow{3}{*}{ Species } & \multicolumn{3}{|c|}{ Adjacent SNH } \\
\hline & & & \multicolumn{3}{|c|}{$\begin{array}{l}\text { Olive Gari-Wood- } \\
\text { grove gue land }\end{array}$} \\
\hline \multirow[t]{13}{*}{ Ambushers } & & & 11 & 16 & 41 \\
\hline & ilodromic & & & & \\
\hline & & gen. sp. & 4 & 6 & 12 \\
\hline & & $\begin{array}{l}\text { Philodromus cf lividus } \\
\text { Simon, } 1875\end{array}$ & & & 1 \\
\hline & & $\begin{array}{l}\text { Philodromus longi- } \\
\text { palpis Simon, } 1870\end{array}$ & & & 2 \\
\hline & Pisaurida & & & & \\
\hline & & Pisaura sp. & & & 1 \\
\hline & homisida & & & & \\
\hline & & gen. sp. & 4 & 4 & 17 \\
\hline & & $\begin{array}{c}\text { Runcinia grammica } \\
\text { (C.L. Koch, 1837) }\end{array}$ & 1 & 3 & 1 \\
\hline & & $\begin{array}{l}\text { Synema globosum } \\
\text { (Fabricius, 1775) }\end{array}$ & 1 & 3 & 4 \\
\hline & & Tmarus sp. & 1 & & \\
\hline & & Xysticus sp. & & & 3 \\
\hline \multirow[t]{3}{*}{ Foliage runners } & & & & & 1 \\
\hline & Iubionida & & & & \\
\hline & & $\begin{array}{l}\text { Clubiona brevipes } \\
\text { Blackwall, } 1841\end{array}$ & & & 1 \\
\hline \multirow[t]{3}{*}{ Ground runners } & & & 4 & 4 & 9 \\
\hline & naphosid & & & & \\
\hline & & gen. sp. & 4 & 4 & 9 \\
\hline \multirow[t]{23}{*}{ Orb weavers } & & & 29 & 80 & 71 \\
\hline & Araneida & & & & \\
\hline & & gen. sp. & 22 & 52 & 34 \\
\hline & & $\begin{array}{l}\text { Aculepeira armida } \\
\text { (Audouin, 1826) }\end{array}$ & & 1 & \\
\hline & & $\begin{array}{l}\text { Agalenatea redii } \\
\text { (Scopoli, 1763) }\end{array}$ & & 1 & \\
\hline & & $\begin{array}{l}\text { Araneus angulatus } \\
\text { Clerck, } 1757\end{array}$ & 3 & & 1 \\
\hline & & $\begin{array}{l}\text { Araneus cf angulatus } \\
\text { Clerck, } 1757\end{array}$ & & & 1 \\
\hline & & $\begin{array}{l}\text { Araneus diadematus } \\
\text { Clerck, } 1757\end{array}$ & 1 & 1 & 8 \\
\hline & & $\begin{array}{c}\text { Araneus marmoreus } \\
\text { Clerck, } 1757\end{array}$ & & & 1 \\
\hline & & $\begin{array}{l}\text { Araniella cucurbitina } \\
\text { (Clerck, 1757) }\end{array}$ & & & 3 \\
\hline & & $\begin{array}{l}\text { Argiope bruennichi } \\
\text { (Scopoli, 1772) }\end{array}$ & & & 1 \\
\hline & & $\begin{array}{l}\text { Cyclosa conica } \\
\text { (Pallas, 1772) }\end{array}$ & & & 7 \\
\hline & & $\begin{array}{l}\text { Cyrtophora citricola } \\
\text { (Forsskål, 1775) }\end{array}$ & & 11 & 2 \\
\hline & & $\begin{array}{l}\text { Gibbaranea bitubercu- } \\
\text { lata (Walckenaer, 1802) }\end{array}$ & & & 1 \\
\hline & & $\begin{array}{l}\text { Hypsosinga sanguinea } \\
\text { (C.L. Koch, 1844) }\end{array}$ & & & 1 \\
\hline & & $\begin{array}{l}\text { Mangora acalypha } \\
\text { (Walckenaer, 1802) }\end{array}$ & 1 & & 6 \\
\hline & & $\begin{array}{c}\text { Zilla diodia } \\
\text { (Walckenaer, 1802) }\end{array}$ & & & 1 \\
\hline & & Zygiella sp. & 2 & 7 & \\
\hline & & $\begin{array}{c}\text { Zygiella x-notata } \\
\text { (Clerck, 1757) }\end{array}$ & & 4 & 1 \\
\hline & ragnathic & & & & \\
\hline & & gen. sp. & & 1 & \\
\hline & & $\begin{array}{l}\text { Metellina segmentata } \\
\quad \text { (Clerck, 1757) }\end{array}$ & & 2 & 2 \\
\hline & & Tetragnatha sp. & & & 1 \\
\hline \multirow{4}{*}{\multicolumn{2}{|c|}{$\begin{array}{l}\text { Sheet web } \\
\text { builders }\end{array}$}} & & 1 & 1 & 5 \\
\hline & & & & & \\
\hline & & gen. sp. & 1 & 1 & 4 \\
\hline & & $\begin{array}{l}\text { Agelena labyrinthica } \\
\text { (Clerck, 1757) }\end{array}$ & & & 1 \\
\hline
\end{tabular}




\begin{tabular}{|c|c|c|c|c|c|}
\hline \multirow[t]{15}{*}{$\begin{array}{l}\text { Space web } \\
\text { builders }\end{array}$} & & & 13 & 60 & 22 \\
\hline & Dictynidae & & & & \\
\hline & & $\begin{array}{r}\text { Brigittea civica } \\
\text { (Lucas, 1850) }\end{array}$ & & 1 & 1 \\
\hline & & Brigittea sp. & & 2 & \\
\hline & Theridiidae & & & & \\
\hline & & gen. sp. & 5 & 25 & 12 \\
\hline & & $\begin{array}{l}\text { Argyrodes argyrodes } \\
\text { (Walckenaer, 1842) }\end{array}$ & 1 & 7 & 2 \\
\hline & & $\begin{array}{l}\text { Heterotheridion nigro- } \\
\text { variegatum imon, } 1873\end{array}$ & 1 & & \\
\hline & & $\begin{array}{l}\text { Kochiura aulica } \\
\text { (C.L. Koch, 1838) }\end{array}$ & 1 & 22 & \\
\hline & & $\begin{array}{l}\text { Parasteatoda lunata } \\
\text { (Clerk, 1757) }\end{array}$ & 1 & & \\
\hline & & $\begin{array}{c}\text { Platnickina tincta } \\
\text { (Walckenaer, 1802) }\end{array}$ & & 2 & 3 \\
\hline & & $\begin{array}{l}\text { Rhomphaea nasica } \\
\quad \text { (Simon, 1873) }\end{array}$ & & & 2 \\
\hline & & $\begin{array}{l}\text { Theridion pinastri } \\
\text { L. Koch, } 1872\end{array}$ & & & 1 \\
\hline & & $\begin{array}{c}\text { Theridion varians } \\
\text { Hahn, } 1833\end{array}$ & & & 1 \\
\hline & & Theridula sp. & 4 & 1 & \\
\hline \multirow[t]{11}{*}{ Stalkers } & & & 20 & 44 & 32 \\
\hline & Mimetidae & & & & \\
\hline & & Ero sp. & & & 3 \\
\hline & & $\begin{array}{l}\text { Mimetus laevigatus } \\
\text { (Keyserling, 1863) }\end{array}$ & & & 1 \\
\hline & Salticidae & & 10 & 22 & 14 \\
\hline & & gen. sp. & 7 & 15 & 11 \\
\hline & & $\begin{array}{c}\text { Evarcha jucunda } \\
\text { (Lucas, 1846) }\end{array}$ & & & 1 \\
\hline & & Heliophanus sp. & & 1 & 1 \\
\hline & & $\begin{array}{l}\text { Heliophanus tribulosus } \\
\text { Simon, } 1868\end{array}$ & & 6 & 1 \\
\hline & & $\begin{array}{l}\text { Icius hamatus } \\
\text { (C.L. Koch, 1846) }\end{array}$ & 2 & & \\
\hline & & $\begin{array}{l}\text { Macaroeris nidicolens } \\
\text { (Walckenaer, 1802) }\end{array}$ & 1 & & \\
\hline \multirow[t]{9}{*}{$\begin{array}{l}\text { Wandering sheet/ } \\
\text { tangle weavers }\end{array}$} & & & 181 & 44 & 77 \\
\hline & Linyphiidae & & & & \\
\hline & & gen. sp. & 1 & 6 & 21 \\
\hline & & $\begin{array}{l}\text { Frontinellina fruteto- } \\
\text { rum (C.L. Koch, 1834) }\end{array}$ & 180 & 38 & 27 \\
\hline & & $\begin{array}{l}\text { Gonatium biimpres- } \\
\text { sum Simon, } 1884\end{array}$ & & & 15 \\
\hline & & $\begin{array}{l}\text { Linyphia triangularis } \\
(\text { Clerck, 1757) }\end{array}$ & & & 14 \\
\hline & $\begin{array}{c}\text { Not } \\
\text { determined }\end{array}$ & & 32 & 54 & 105 \\
\hline & Total & & 291 & 303 & 363 \\
\hline & Total species & & 12 & 14 & 31 \\
\hline
\end{tabular}

